\title{
Quantification of Urban Expansion Using Geospatial Technology-A Case Study in Bangalore
}

\author{
Puspa P. Dash, Ritu Kakkar, V. Shreenivas, P. Jeya Prakash, D. J. Mythri, \\ K. H. Vinaya Kumar, Vanashree Vipin Singh, R. M. N. Sahai \\ Centre for Lake Conservation, Environmental Management and Policy Research Institute, Doresanipalya Forest \\ Campus, Bangalore, India \\ Email:dash03@gmail.com
}

Received 26 October 2015; accepted 20 December 2015; published 23 December 2015

Copyright (C) 2015 by authors and Scientific Research Publishing Inc.

This work is licensed under the Creative Commons Attribution International License (CC BY).

http://creativecommons.org/licenses/by/4.0/

(c) (i) Open Access

\begin{abstract}
Quantification of urban expansion helps us to understand human induced effects on the environment in a temporal scale. Growing urbanization in Bangalore has resulted in demand for more space and resources. Since last 15 years the landuse and landcover of Bangalore area has been changed drastically due to increase in settlement, urban infrastructure, opening of roads and metros etc. Using geospatial tools, we studied the changes in landuse and landcover over 19 years (1992-2011) of period and changes in transport network over 41 years (1970-2011) in parts of Bangalore. Thus, the current study shows that the built-up area has been increased drastically, tree cover areas have been converted to agricultural lands and agricultural lands to built-up areas due to urbanization. There are also changes in drainage pattern, transport network and encroachment of water bodies. Thus the whole environment is getting affected adversely due to unplanned and rapid urban sprawl.
\end{abstract}

\section{Keywords}

Urban Expansion, Land Use, Land Cover, Change Analysis, Satellite Data, GIS

\section{Introduction}

Land Use (LU) Land Cover (LC) change is also known as land transformation. The modification of lands by human being has started from the dawn of civilization for their basic needs, but the current rate of LU pattern is leading to more negative impacts on the environment. Rapid growth of urbanization and developmental activi-

How to cite this paper: Dash, P.P., Kakkar, R., Shreenivas, V., Prakash, P.J., Mythri, D.J., Kumar, K.H.V., Singh, V.V. and Sahai, R.M.N. (2015) Quantification of Urban Expansion Using Geospatial Technology-A Case Study in Bangalore. Advances in Remote Sensing, 4, 330-342. http://dx.doi.org/10.4236/ars.2015.44027 
ties are the main threats to the natural ecosystem. Due to the demand for more space, the LC of the earth has been changing rapidly into several human LU practices such as built-up areas, commercial spaces, transport network etc. The knowledge of LU and LC has become increasingly important as the National plans to overcome the problems of haphazard, uncontrolled development, deteriorating environmental quality, loss of prime agricultural lands, destruction of important wetlands, and loss of fish and wildlife habitat [1].

Both population growth and urbanization are interlinked and continuous phenomenon, so in the present scenario there is an urgent need for proper planned development, so that the ecosystem in and around the urban fringes can be saved. The study of LU-LC change analysis has been given more importance after the development of Remote Sensing (RS) technology since 1980's. LU study until the late 60's and early 70's has been based on conventional surveys which are very expensive and time consuming. The remotely sensed data from space borne sensors provide repetitive coverage and data in digital form which is amenable to computer analysis using GIS [2]. To quantify the amount of changes in land from one form to another, the advanced technology of geospatial analysis (RS and GIS) in temporal domain has given a significant contribution to the world. LU/ LC change has also tremendous effect on water quality, land and air resources, ecosystem processes and function, and climate [3]; biodiversity [4], soil degradation [5] and the ability of natural systems to support life [6]. There are a number of international research projects on dynamics of LU/LC analysis. Some of the examples are The International Geosphere-Biosphere Project (1988) and the LU/LC Change program which were initiated in a bid to construct an updated and accurate database concerning observed changes, their meaning, pace, magnitude and driving forces behind such changes [7]. Quantifying the changes in the landscape is very important for clear understanding of the spatial and structural variability in the LU and their associated ecological effects [8] [9].

Pertaining to the growth of Bangalore City, some studies have been done. [10] analysed the changes in land use and land cover pattern using both historical maps and RS imagery. Bangalore urban district LU mapping and LC assessment was carried out jointly by Indian Space Research Organization (ISRO/DOS) and Karnataka State Remote Sensing Agency (1996-2002) as a prototype study for Natural Resources Census (ISRO/KSRSAC, 2005). A comparative assessment has been done by [2] on population, economy, urban sprawl in both Bangalore and Hyderabad cities to analyse the land use changes. Bangalore, which is also known as the city of lakes, garden city and pensioner's paradise, over the period of time, has grown significantly both in technology and urbanization and has been named as "Silicon Valley". Bangalore city was awarded "Indira Priyadarshini Vruksha Mitra" by the Central Government in 1980 for its extensive green cover. But today lung space is shrinking in the city and the core areas have lost green cover with increase in concrete structures [11]. The vastly growing population will turn Bangalore into a "concrete forest" within a time span of 15 - 20 years. This study was conducted to review the past and present situation and trend of urban expansion in part of Bangalore district. The objective of the present study is to analyse the quantity of change of LC into different LU patterns over 19 years period and also changes in transport network and drainage pattern over 41 years of time period by using geospatial technology.

\section{Study Area}

Study area is situated at Latitude $12^{\circ} 53^{\prime} 53^{\prime \prime}$ and Longitude $77^{\circ} 23^{\prime} 46^{\prime \prime}$ of Bangalore district of Karnataka state (Figure 1). The study area consists of 31 villages. The area is chosen in such a manner that, the impact of urbanization can be studied very clearly. The area is segregated into three different zones on the basis of developmental activities. These zones are already developed Sir Mokshagundam Visveswaraiah Layout (SMVL), developing layout Nada Prabhu Kempegowda Layout (NPKL) and yet to develop i.e. Green Belt (GB) area (Figure 2).

\section{Materials and Methods}

For the current study Arc View 3.2a and Quantum GIS 1.6.0 softwares are used. Toposheets of 1:50,000 scale used to quantify the past roads, drainages, water bodies etc. Landsat data and Aster data were used for landuse (LU)/landcover (LC) classification, current road network, drainage pattern analysis, water bodies and for LU-LC change analysis.

Toposheets of 1970s were scanned and then georeferenced. After georeferencing, on screen visual interpretation method was followed to create zone maps (NPKL, SMVL and GB), drainages, water bodies, roads, rail and settlement maps. For the current status of water bodies, drainages, road and settlements satellite imageries were 


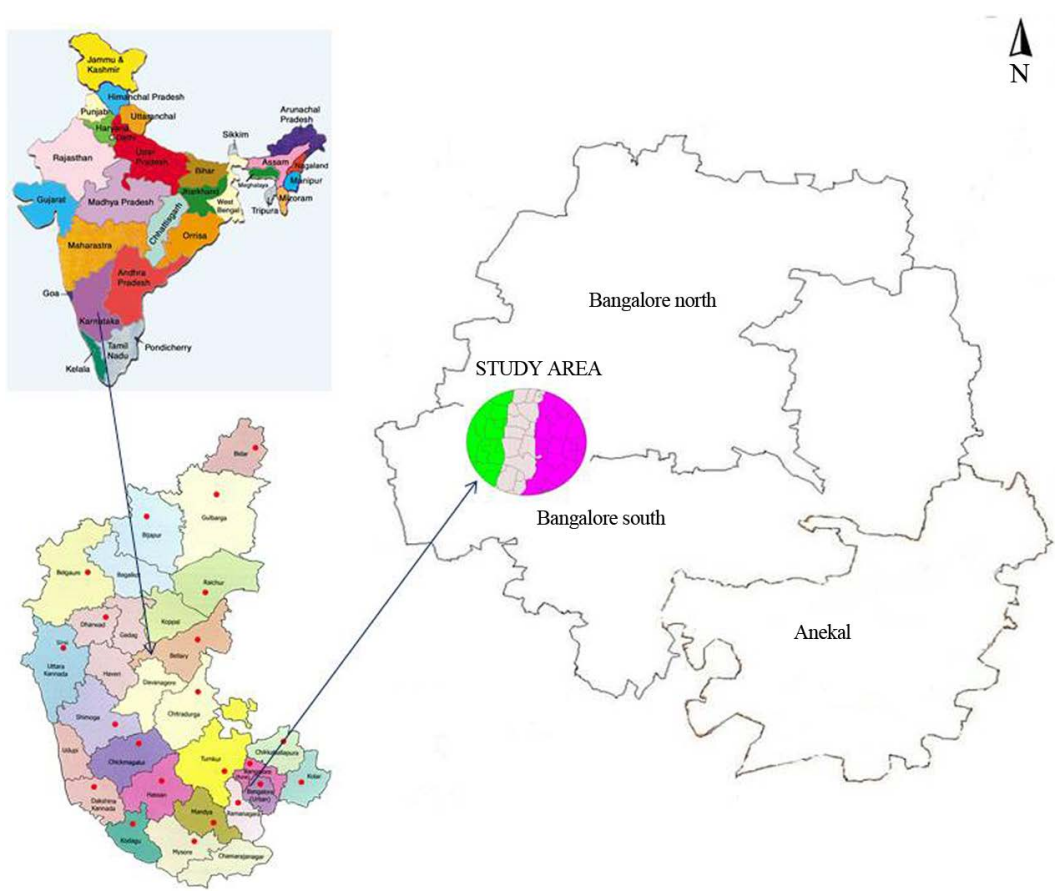

Figure 1. Study area.

Area in Percentage

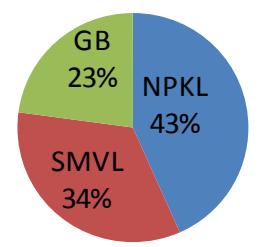

Figure 2. Area covered by different zones in the study area.

digitized and used for further analysis. For changes in land use land cover pattern, Landsat data of 1992, 2000 and Aster data of 2011 were used. On screen visual interpretation method was followed to create the LU/LC maps of 1992, 2000 and 2011. The image elements that are considered for interpretation are tone, texture, size, shape, shadow association and physiography. Google earth data and information collected during the field work are taken for the classification of images into different classes. The interpretation key and field knowledge were utilised for the preparation of LU/LC maps. Intensive field work has been carried out to collect the GPS locations of all the water bodies big to small which are locally named as kere, katte and kunte and also other features and then same was verified on the prepared maps.

To know the gradient of the area, contours are digitized from toposheets and Digital Elevation Model was prepared using Quantum GIS software.

Water spread areas for major water bodies were mapped for two seasons (summer and monsoon) by using GPS tracking method. The water spread area was mapped to know the seasonal reduction in water spread area.

\section{Results and Discussion}

In the entire study area a total of 117 water bodies were identified which includes very small to large water bodies. Out of these 117 water bodies, 36 are not existing and 81 are existing water bodies. According to the connectivity of drainages to the lakes, a buffer of $2 \mathrm{~km}$ from the study area boundary was taken into consideration while doing the analysis. The general drainage pattern of the study area is from the North to the South. The main rivers are Arkavathi and Vrishibhavati rivers. Arkavathi river is flowing in the northern part and Vrishibhavati 
river is flowing in the southern part of the study area. Though these two rivers are flowing outside of the study area, all the drainages are tributaries of Vrishibhavati river. The direction of flow of water is from the north to south as the northern part is having high slope as compared to southern part. The numbering of the streams done by following Strahler stream order (Figure 3) based on a hierarchy of tributaries [12]. The order of drainage in the present area is up to $4^{\text {th }}$ order. $1^{\text {st }}$ and $2^{\text {nd }}$ order drainages are the minor drainages whereas $3^{\text {rd }}$ and $4^{\text {th }}$ order drainages are the major drainages.

\subsection{Quantification of Urban Expansion}

Bangalore was established during 1537 by Kempe Gowda-I, by building a mud fort. Within the fort, the town was divided into Petesor localities such as Chickpete, Dodpete, Balepete, Cottonpete and other areas earmarked for different trades by artisans [13]. He also built many tanks, temples which have made village Bangalore into a cultural city. After him, his son Kempe Gowda-II has developed the city up to some extent. From 1673-1790 A.D., Mughal Kings Khasim Khan, Hyder Ali, Tipu Sultan ruled the area and built it into a small town of five Kms in circumference. Britishers built many commercial places, railway line etc. Bangalore continued to grow and several public sector industries were set up from 1940-1970 transforming it into a science and technology centre. By 1961, Bangalore had become the $6^{\text {th }}$ largest city in India with a population of $1,207,000$. Between 1971 and 1981, Bangalore's growth rate was 76\%, the fastest in Asia. By 1988, the Electronic City had been developed and Bangalore emerged as India's software capital. Consequently the 1990's saw a construction boom fuelled by Bangalore's growing reputation as “India's Silicon Valley”, which saw many young professionals migrate to the city [13]. This is how the urbanization in Bangalore started and due to all the above said reasons it is expanding day-by-day and there is increasing demand for space. Urban growth is occurring unscientifically in the whole area, which is encumbering the natural landscape. Bangalore's population was three lakhs in 1931 and now the population is more than 80 lakhs (Figure 4).

The above statistics shows the tremendous growth of population in Bangalore city and in order to meet the growing need, the city area is also expanding to the rural fringes.

\subsubsection{LU/LC Mapping}

The LU/ LC map has been prepared for 19 years viz, 1992, 2000 and 2011 years respectively. The LU/LC classes derived are: built-up area, open ground/agricultural land, tree cover area and water body. The map of 1992 (Figure 5) indicates that, the tree cover areas are mostly surrounded along the lakes and the drainages. The

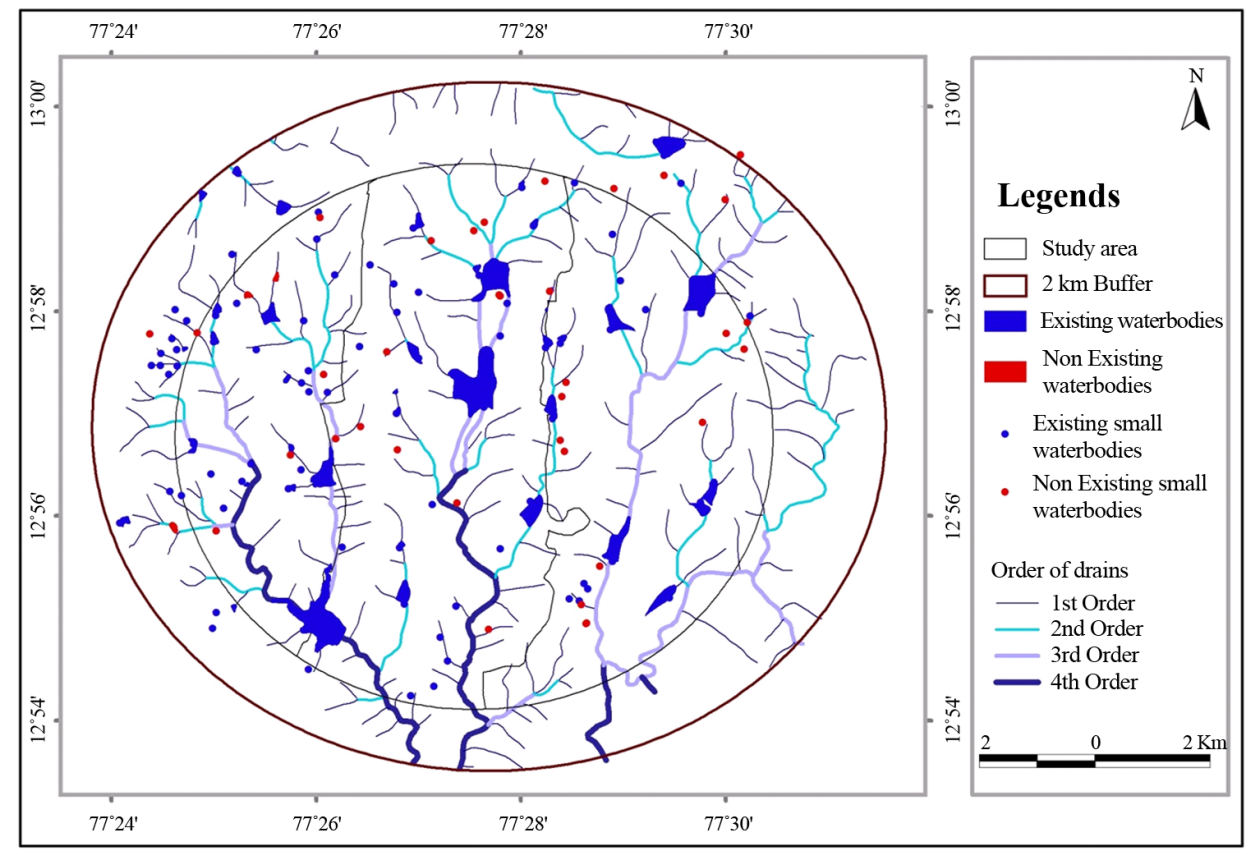

Figure 3. Drainage pattern and status of water bodies in the study area. 


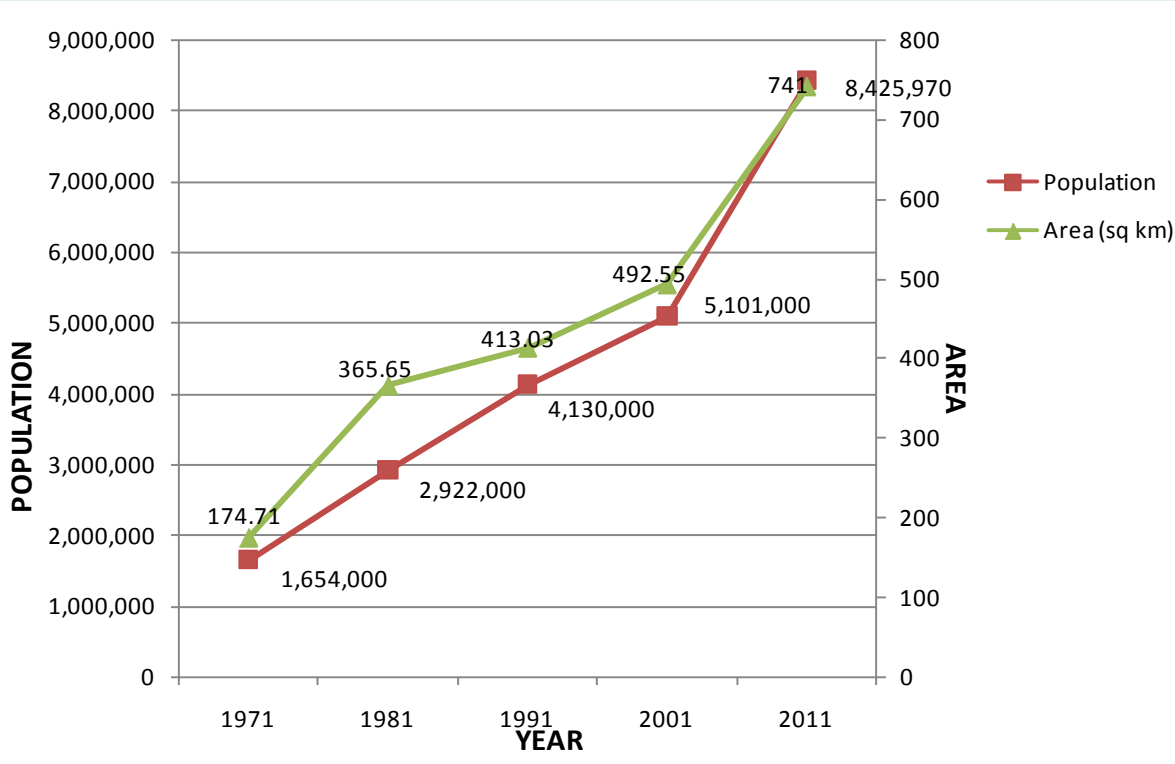

Figure 4. Population statistics of Bangalore over 40 years.

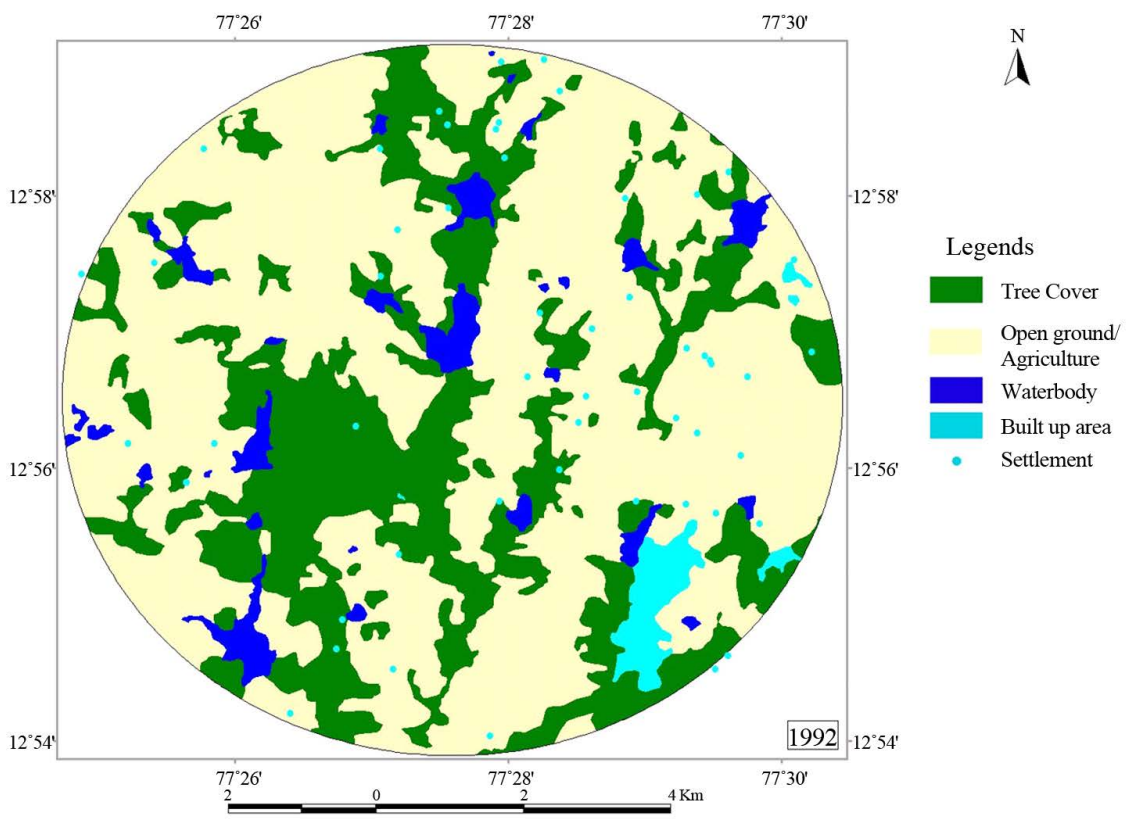

Figure 5. Land use and land cover map of 1992.

tree covers are continuous and less fragments in 1992. While comparing 1992 and 2000 LU/LC maps (Figure 5, Figure 6), the result indicates that there is increase in built-up areas from 1.49 to 3.89 sq.km (Table 1). In 2011 (Figure 7), map clearly shows that the urbanization has grown extensively in SMVL and covers $18.22 \%$ of the area. In the last 19 years, it has been observed that open ground/Agricultural land have been decreased from 53.84 sq.km to 50.26 sq.kms. There is almost $10.8 \%$ of the tree cover area has been decreased in past 19 years and at the same time built up area has been increased almost $16.3 \%$. The built up areas which are in small patches have become more prominent and continuous and the tree cover areas are more fragmented.

\subsubsection{Transport Network}

The result shows that the density of road has increased during last 41 years. It has been observed that most of the unmetalled roads have been converted into metalled roads and there are more than 30 new metalled roads and 


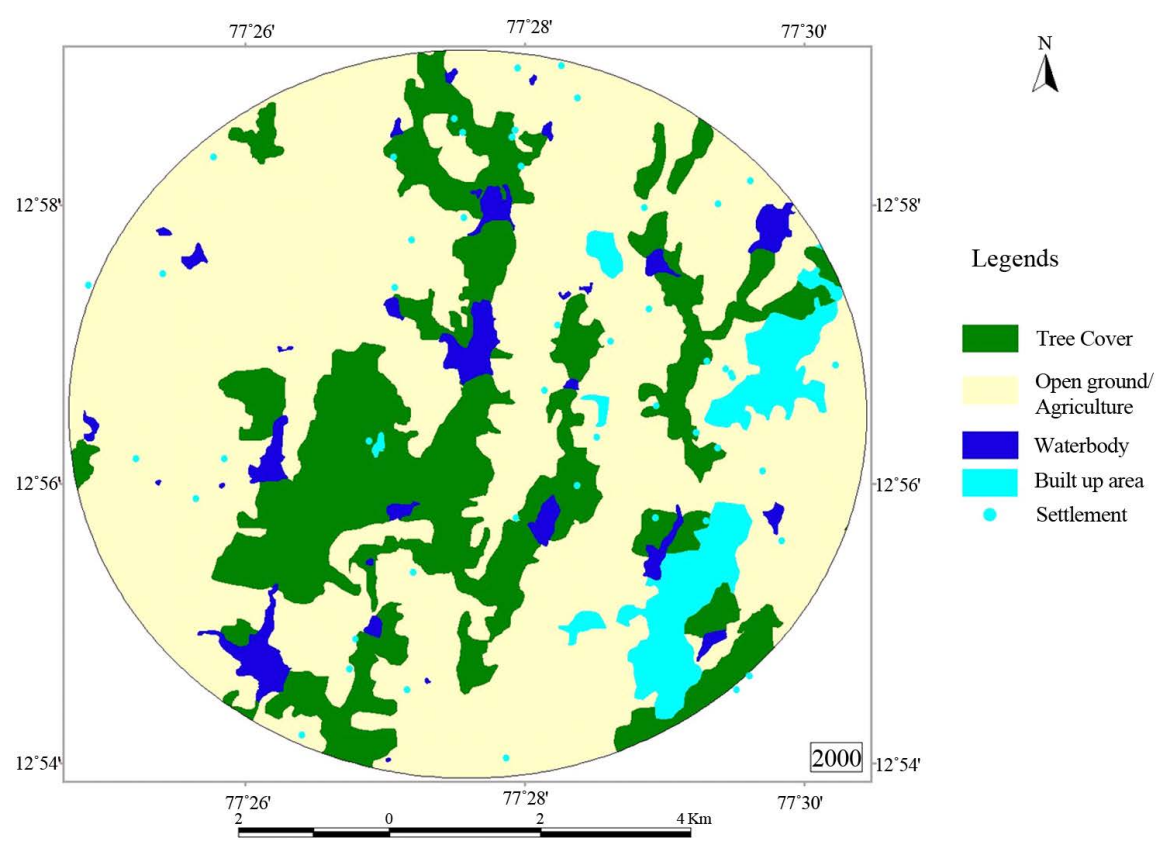

Figure 6. Land use and land cover map of 2000.

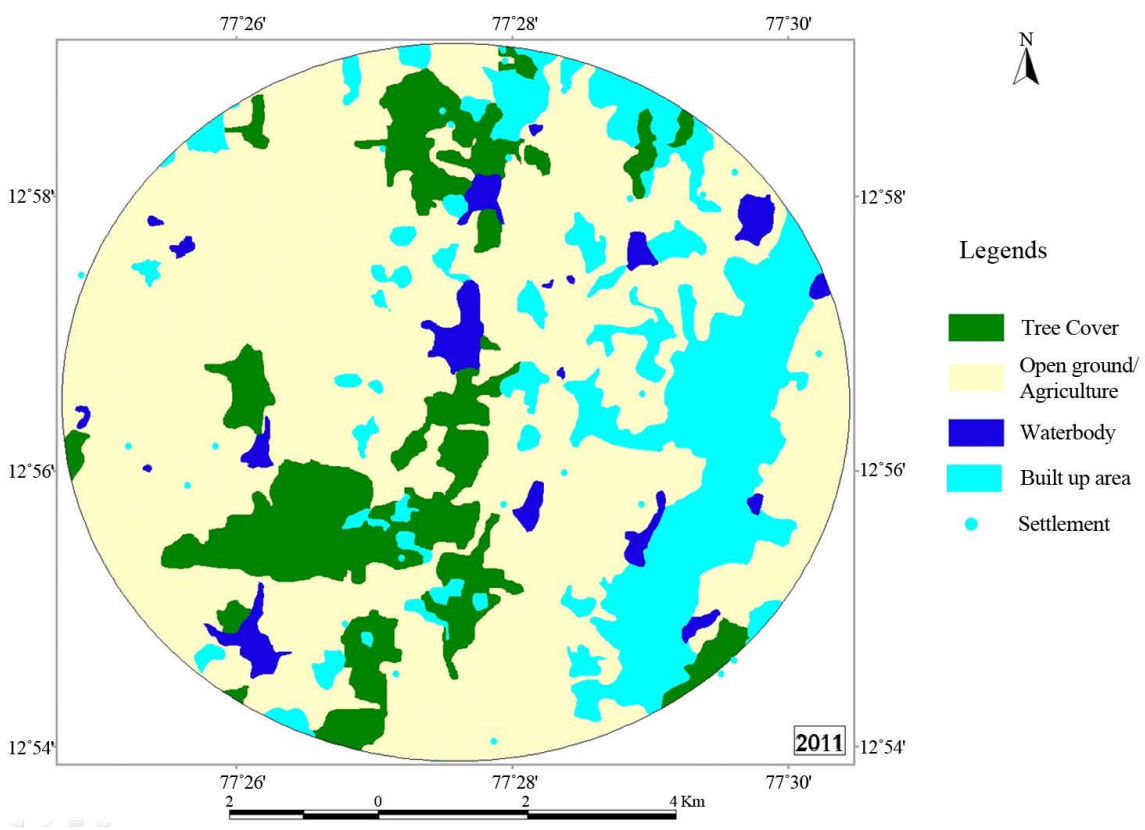

Figure 7. Landuse Landcover map 2011.

Table 1. LU/LC change analysis over the time period of 19 years.

\begin{tabular}{ccccccc}
\hline $\begin{array}{c}\text { Land use/Land cover } \\
\text { Type }\end{array}$ & $\begin{array}{c}\text { 1992 Area } \\
\text { in sq.km }\end{array}$ & $\begin{array}{c}\text { Area } \\
\text { in \% }\end{array}$ & $\begin{array}{c}\text { 2000 Area } \\
\text { in sq.km }\end{array}$ & $\begin{array}{c}\text { Area } \\
\text { in \% }\end{array}$ & $\begin{array}{c}\text { 2011 Area } \\
\text { in sq.km }\end{array}$ & $\begin{array}{c}\text { Area } \\
\text { in \% }\end{array}$ \\
\hline Built up area & 1.49 & 1.91 & 3.89 & 4.98 & 14.22 & 18.22 \\
Open ground/Agriculture & 53.84 & 68.99 & 52.97 & 67.88 & 50.26 & 64.40 \\
Tree cover & 19.52 & 25.01 & 18.53 & 23.74 & 11.05 & 14.16 \\
Water body & 3.19 & 4.09 & 2.65 & 3.40 & 2.51 & 3.22 \\
\hline
\end{tabular}


many new unmetalled roads built in the whole study area and one State Highway is passing through the study area. Four water bodies namely, Mangannahalli lake-1 (10\%), Manganahalli lake-2 (5\%), Ramsandra Chikere (40\%) and Komgatta lake (15\%) are affected due to the construction of NICE road (Figure 8). As a result, areas of these water bodies have been reduced. Among these fours lakes, Ramsandra Chikere has been affected more. The number of roads has increased in SMV layout due to urbanization and infrastructure development (Figure 8 and Figure 9). There is one railway line present in the Southern part of the study area. This is the only railway line present in the study area and there is no further development in railway line in the last 41 years.

\subsubsection{Digital Elevation Modelling (DEM)}

Digital Elevation Modelling (DEM) has been created by using geospatial technique to know the gradient of the study area. DEM gives the three dimensional digital representation of a topographic surface. The elevation of the study area varies from $760 \mathrm{~m}$ to $900 \mathrm{~m}$. Herohalli village is at the highest peak and Bhimankuppe, Challahatta villages are with low terrain in the whole study area. It can be clearly inferred that the gradient of the study area is from the North to South and direction of flow of water is also from the North to South (Figure 10).

\subsubsection{Changes in Drainage Pattern}

The comparative analysis of drainage pattern of 1970 (Figure 11) and 2011 (Figure 12) gives the inference that few primary drainages from the Northern part of the study area have disappeared. Disappearance of these drain-

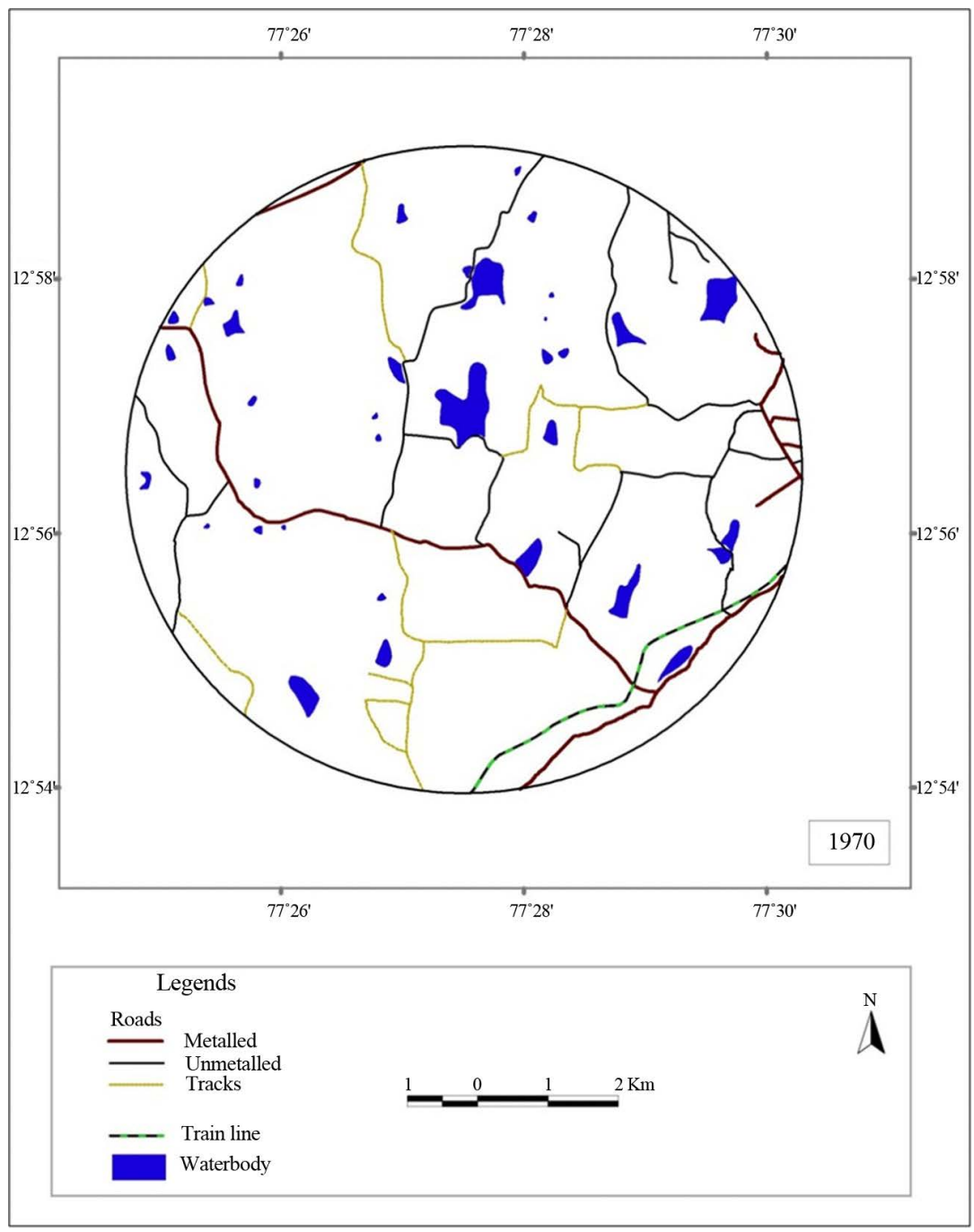

Figure 8. Road and railway network in 1970. 


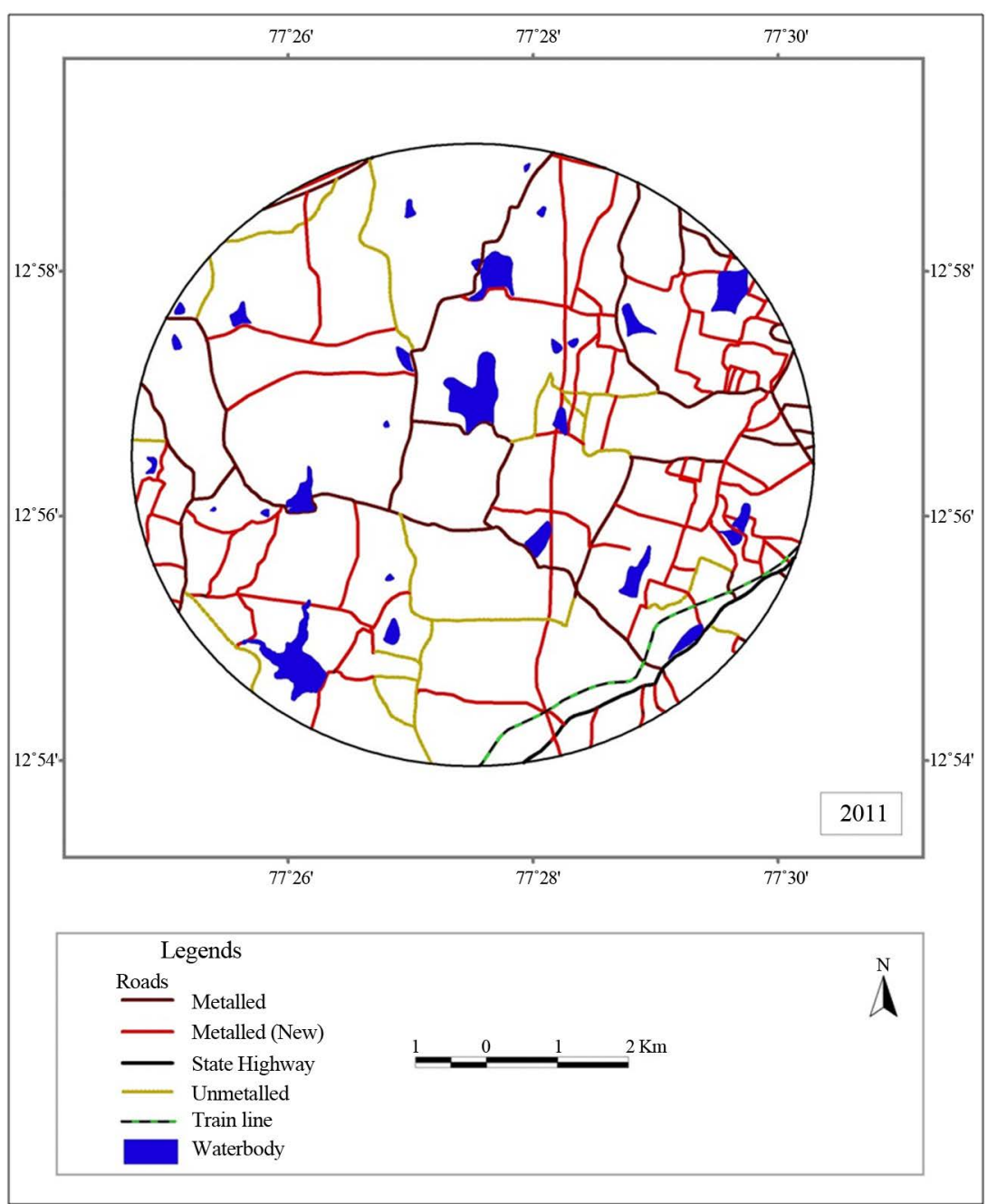

Figure 9. Road and railway network in 2011.

\section{Digital Elevation Model}

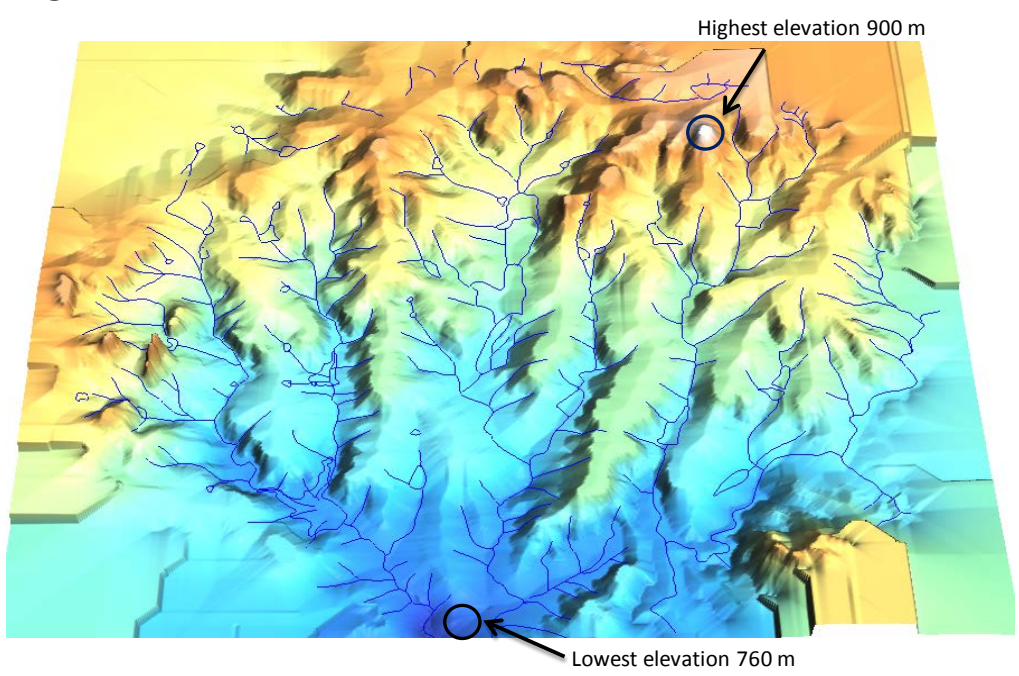

Figure 10. Digital elevation model of the study area. 


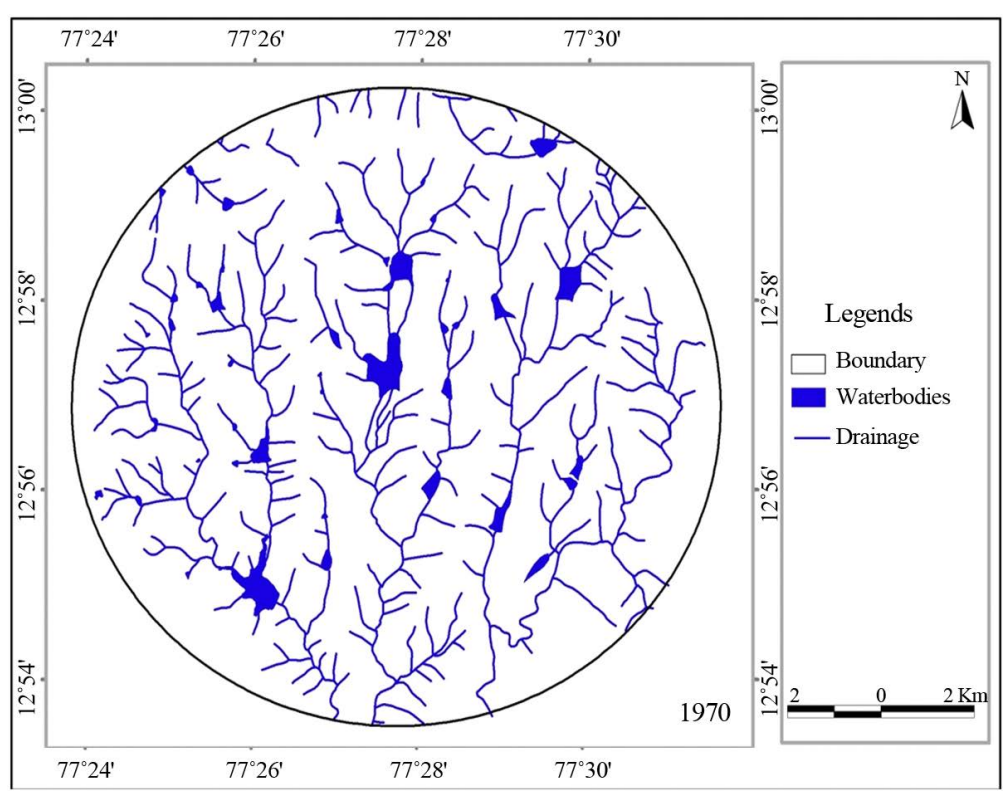

Figure 11. Drainage map on the year 1970.

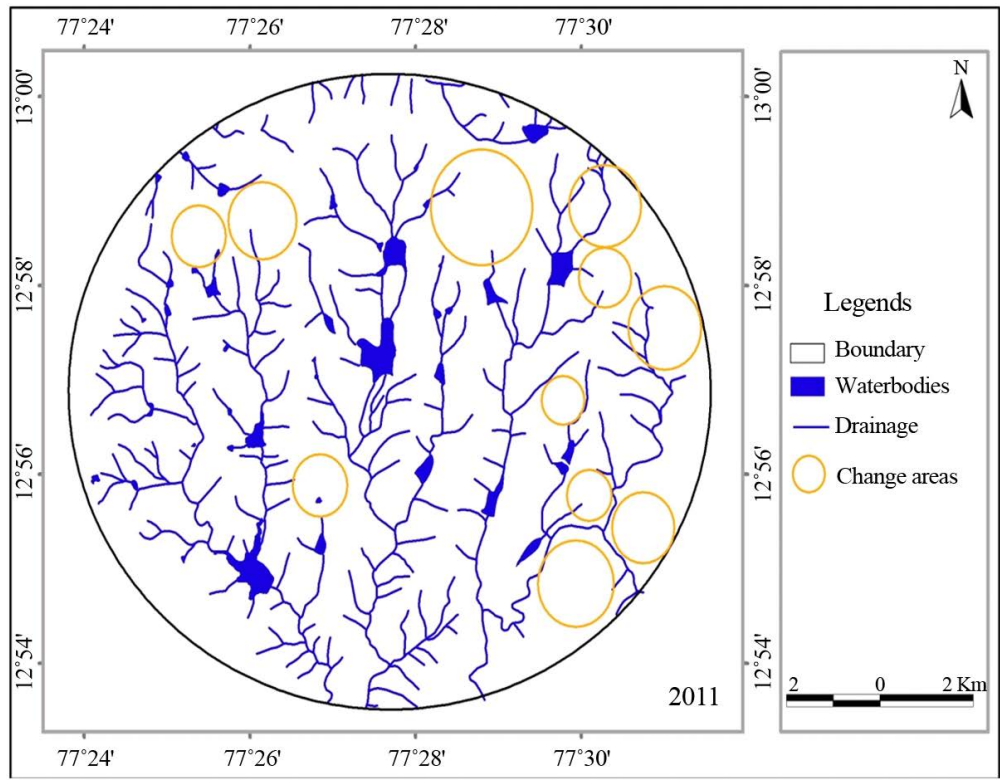

Figure 12. Drainage map on the year 2011.

ages are observed in Herohalli, Gidadakonenahalli, Mallathahalli, Nagdevanahalli and Valgerahalli villages near Kengeri village in the eastern part of the study area. Some changes are also seen in the middle part of Kodigehalli, Sulikere, Kommaghatta villages and in the Western part in Channenahalli and Honniganahatti villages. The change pattern is seen more in the Eastern part due to urbanization. The construction of roads and buildings has affected most of these drainages.

\subsubsection{GPS Mapping of Water Spread Area}

An attempt has also been made to know the seasonal water holding capacity of lakes present with in the study area. GPS tracking has been done for the water bodies to know the extent of water spread area in both monsoon (June-August) and summer (Mar-May) seasons. Seasonal water spread area of water bodies of the study area are tabulated in Table 2. Some of the small water bodies were dried during summer season. The analysis shows 
Table 2. GPS water spread area.

\begin{tabular}{|c|c|c|c|c|}
\hline Water-Body Name & $\begin{array}{c}\text { Extent } \\
\text { (Acre-Gunta) }\end{array}$ & $\begin{array}{c}\text { Monsoon } \\
\text { (Acre-Gunta) }\end{array}$ & $\begin{array}{c}\text { Summer } \\
\text { (Acre-Gunta) }\end{array}$ & $\%$ of Reduction \\
\hline Herohalli Lake & 34.33 & 13.34 & 2.7 & 31 \\
\hline Kannalli Lake & 68.09 & 57.3 & 6.51 & 74.59 \\
\hline Kodigehalli Lake & 9.25 & 6.24 & 1.36 & 53 \\
\hline Ajjegowdana Katte & 3.32 & 0.15 & Dry & - \\
\hline Mallathalli Lake & 72.15 & 57.41 & 33.15 & 34 \\
\hline Manganahalli Lake-2 & 4 & 2.02 & 1.45 & 14 \\
\hline Bhimanakuppe Hosakere & 97.08 & 75.71 & 11.88 & 66 \\
\hline Dasappana Kere & 5.24 & 3.55 & 0.05 & 67 \\
\hline Hunsemaradapalya Lake & 13.18 & 8.65 & Dry & - \\
\hline Kenchanapura Lake & 17.2 & 7.43 & 2.9 & 26 \\
\hline Kommaghatta Lake & 37.05 & 29.79 & 27.28 & 7 \\
\hline Hosa Bairohalli & $\approx 02.00$ & 2.25 & 1.83 & 21 \\
\hline Bajjana Katte & 2.35 & 0.1 & 0.05 & 2 \\
\hline K.K Hosakatte & 2.08 & 1.46 & 0.68 & 38 \\
\hline Margondanahalli Hosakere & 46.31 & 37.97 & 29.7 & 18 \\
\hline Gowdana Kere & 5.33 & 6.56 & 3.24 & 62 \\
\hline Karab Keire & 3.06 & 0.23 & 0.01 & 7 \\
\hline Hosa Katte & 2 & 0.57 & 0.24 & 16 \\
\hline Gulganjanaalli Katte & $\approx 00.20$ & 0.25 & 0.05 & 10 \\
\hline Ramasandra Lake & 135.14 & 86.27 & 19.31 & 50 \\
\hline Kempuhuli Kere & 2 & 0.5 & 0.26 & 12 \\
\hline Basavanapalya Lake & 8 & 3.6 & 3.06 & 7 \\
\hline Basavana Katte & 4 & 1.02 & 0.38 & 16 \\
\hline Muddayyanapalya Lake & 10 & 2.43 & 0.27 & 22 \\
\hline Halubhavi & $\approx 30.00$ & 7.37 & 1.74 & 56 \\
\hline Yelchguppe Lake & 23.19 & 12.5 & 4.19 & 36 \\
\hline Bairana Katte & 7.35 & 6.91 & 4.36 & 35 \\
\hline Cholana Katte & 1 & 0.49 & 0.27 & 21 \\
\hline Above 100 acres & $100-50$ acre & 50 - 25 acres & $25-10$ acres & 10 - 5 acres \\
\hline
\end{tabular}

Ramsandra lake (the biggest lake in the study area which covers 135 acres) has 86.27 acres of water spread area in monsoon season and has reduced to 19.31 acres in summer season (Figure 13). Bhimanakuppe Hosakere, Kannali lake, Margondanahalli Hosakere are the three lakes, which have water spread area in the range of 50 100 acres. The actual area of Bhimanakuppe Hosakere is 97.08 acres; the water spread area during monsoon is 75.71 acres and 11.88 acres in summer seasons (Figure 14). Likewise the water spread area for Margondanahalli Hosakere (Figure 15) is 57.41 and 33.15 acres in monsoon and summer season respectively. Table 2 shows that the Kannali lake has highest percentage (74.5\%) of water spread area reduction followed by Dasapan Kere (67\%), Bhinkuppe Hosakere (66\%) and Gowdana Kere (62\%). 


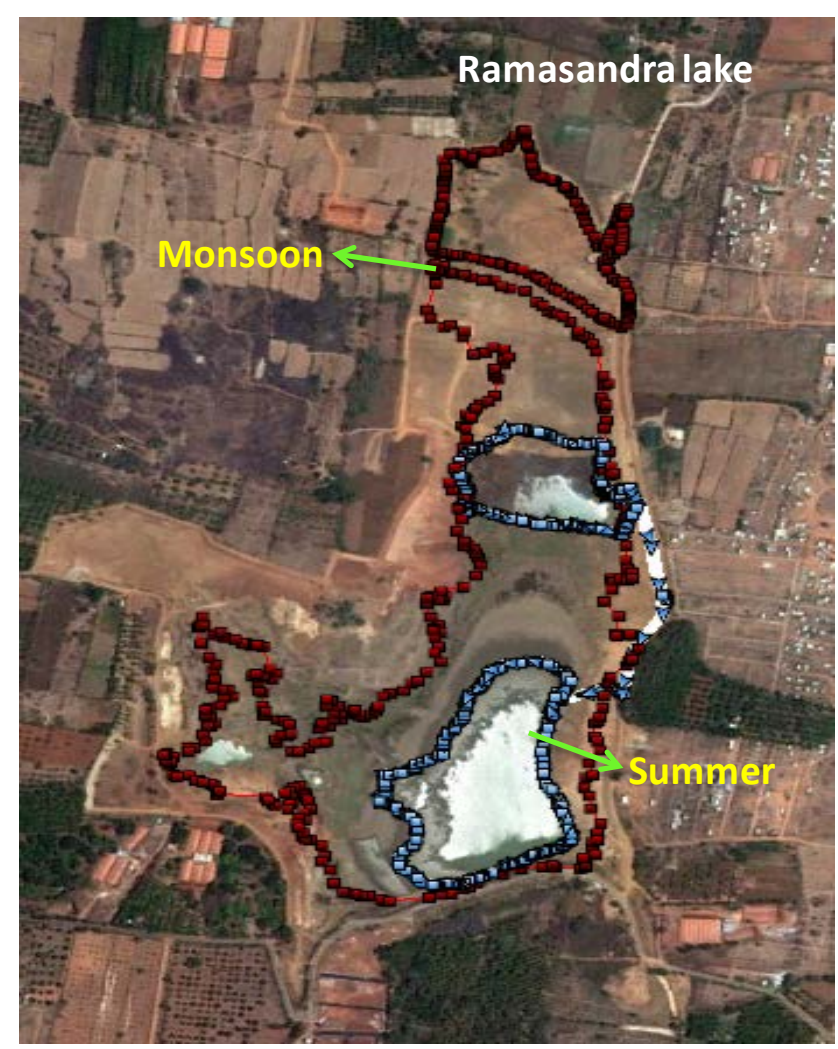

Figure 13. Seasonal water spread area of Ramasandra lake.

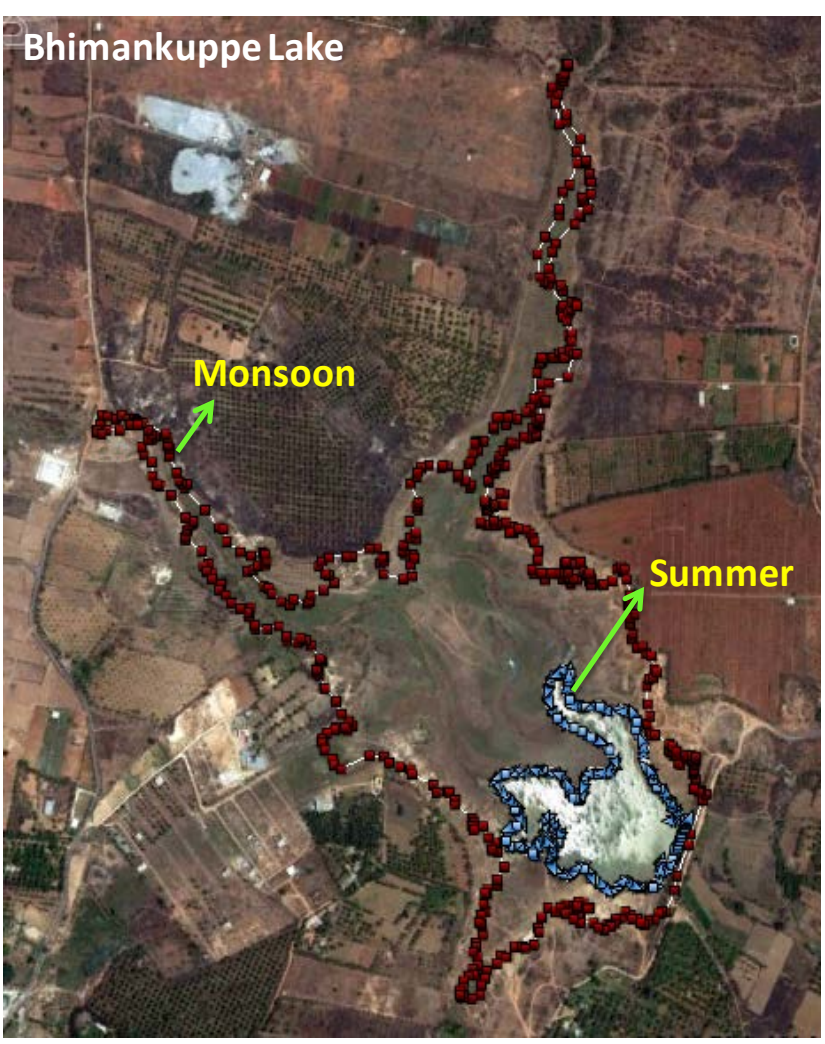

Figure 14. Seasonal water spread area of Bhimankuppe lake. 


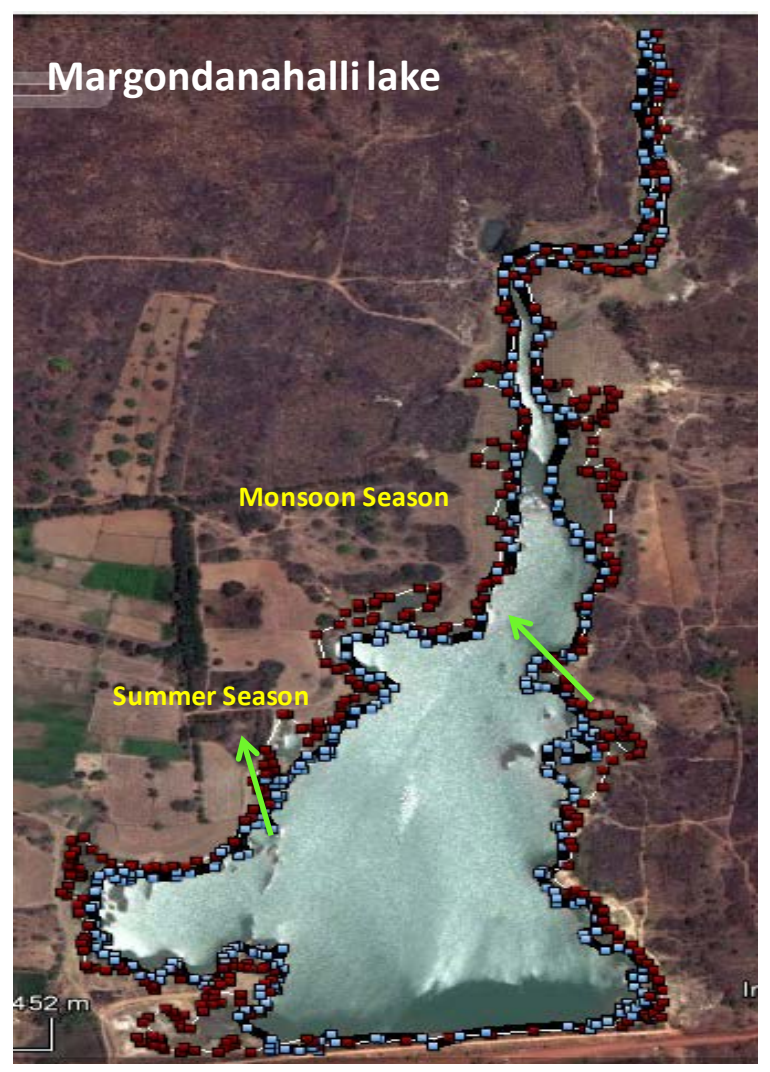

Figure 15. Seasonal water spread area of Margondanahalli lake.

\section{Conclusion}

This study highlighted the urban expansion analysis of Bangalore city by using geospatial technology. The study has analysed the trend of urban growth which is main driver for current land use and land cover changes. Rapid economic devolvement, transformation of city from rural to urban and improvement in standard of living in recent decade are the main contributors to the land transformation. From the above study, it is concluded that in SMV layout the entire area is urbanized and few vacant lands are left. The anthropogenic pressure on lakes is higher in the SMVL areas as compared to the others (NPKL and Greenbelt area). The most polluted lake is Bandematta lake in SMVL, which is one of the examples of impact of urbanization on lakes. The city is expanding from the East to West. The layout planning for built-up area is demarketed in SMV layout on ground and construction work also in progress in many areas. In NPK layout plans are approved and in another ten years the whole area will be fully urbanized. In the greenbelt area, local houses are there, but not much urbanization comes up. In another 10 - 20 years, the green belt area will also be fully urbanized. [11] suggested that the amount of transformation that took place in 30 years is taking place just within 5 years i.e. the acceleration of changes are faster every year. So, the rate of change in ecological spaces and bio-geography of the area is also faster and negative. There are numbers of examples in Bangalore city where the lake lands (Dharmambudhi tank, Karanji tank, Samangi tank, Millers tank, Siddikatte tank, Mathikere tank, Binnypet tank, Juganhalli tank, Challaghatta tank, Koramangala tank, etc.) had converted into built-up areas, commercial spaces, as a result of urbanization. Therefore, before the growth of full urbanization there is an urgent need for proper utilization of land resources with the application of advanced scientific technologies in order to protect the green cover and water bodies along with their drainages present in the urban fringes.

\section{Acknowledgements}

All the authors are thankful to GoK and CiSTUP, IISc, Bangalore, Karnataka for funding the project. We are also thankful to all the departments and people who have helped us for successful completion of the project. Our 
special thanks to the former Professor of Fishery, Bangalore University \& Former Acting Director, National Assessment and Accreditation Council (NAAC), Dr. S. Ravichandra Reddy for reviewing the project work.

\section{References}

[1] Anderson, J.R., Hardy, E.E., Roach, J.T. and Witmer, R.E. (1976) A Land Use and Land Cover Classification System for Use with Remote Sensor Data. Geological Survey Professional Paper 964, United States Government Printing Office, Washington.

[2] Iyer, N.K., Kulkarni, S. and Raghavaswamy, V. (2007) Economy, Population and Urban Sprawl a Comparative Study of Urban Agglomerations of Bangalore and Hyderabad, India Using Remote Sensing and GIS Techniques. PRIPODE workshop on Urban Population, Development and Environment Dynamics in Developing Countries, Nairobi, 11-13 June 2007, 37 p.

[3] Lambin, E.F., Rounsevell, M.D.A. and Geist, H.J. (2000) Are Agricultural Land-Use Models Able to Predict Changes in Land-Use Intensity? Agriculture, Ecosystems \& Environment, 82, 321-331. http://dx.doi.org/10.1016/S0167-8809(00)00235-8

[4] Liu, J. and Ashton, P.S. (1998) FORMOSAIC: An Individual-Based Spatially Explicit Model for Simulating Forest Dynamics in Landscape Mosaics. Ecological Modelling, 106, 177-200. http://dx.doi.org/10.1016/S0304-3800(97)00191-9

[5] Trimble, S.W. and Crosson, P. (2000) Land Use: U.S. Soil Erosion Rates. Myth and Reality. Science, 289, 248-250. http://dx.doi.org/10.1126/science.289.5477.248

[6] Vitousek, P.M., Mooney, H.A., Lubchenco, J. and Melilo, J.M. (1997) Human Dominated Earth’s Ecosystems. Science, 277, 494-499. http://dx.doi.org/10.1126/science.277.5325.494

[7] Mather, A.S. (1999) Land Use and Cover Change. Land Use Policy, 16, 143.

[8] Turner, M.G. (2005) Landscape Ecology in North America: Past, Present and Future. Ecology, 86, 1967-1974. http://dx.doi.org/10.1890/04-0890

[9] Kabba, V.T.S. and Li, J.F. (2011) Analysis of Land Use and Land Cover Changes, and Their Ecological Implications in Wuhan, China. Journal of Geography and Geology, 3, 104-118.

[10] Behera, G., Nageswara Rao, P.P., Dutt, C.B.S., Manikiam, B., Balakrishnan, P., Krishnamurthy, J., Jagadeesh, K.M., Ganesha Raj, K., Diwakar, P.G., Padmavathy, A.S. and Parvathy, R. (1985) Growth of Bangalore City since 1900 Based on Maps and Satellite Imagery. ISRO Technical Report No.: 55, Trivandrum.

[11] Priya, N. and Hanjagi, A.D. (2009) Land Transformation: A Threat on Bangalore's Ecology—A Challenge for Sustainable Development. Theoretical and Empirical Researches in Urban Management Special Number 1S/April 2009: Urban Issues in Asia.

[12] Horton, R.E. (1945) Erosional Development of Streams and Their Drainage Basins: Hydro-Physical Approach to Quantitative Morphology. Geological Society of America Bulletin, 56, 275-370. http://dx.doi.org/10.1130/0016-7606(1945)56[275:EDOSAT]2.0.CO;2

[13] Vagale, U.K. (2004) Bangalore-Future Trends in Public Open Space Usage: Case Study. Master’s Thesis, Virginia Polytechnic Institute and State University, Bangalore. 